\title{
THE USE OF LIQUID PETROLEUM JELLY IN THE PREVENTION OF PERINEAL LACERATIONS DURING BIRTH ${ }^{1}$
}

\author{
Natalúcia Matos Araújo ${ }^{2}$ \\ Sonia Maria Junqueira Vasconcellos de Oliveira ${ }^{3}$
}

Araújo NM, Oliveira SMJV. The use of liquid petroleum jelly in the prevention of perineal lacerations during birth. Rev Latino-am Enfermagem 2008 maio-junho; 16(3):375-81.

Most of vaginal births are accompanied by lacerations in the genital tract. This was a randomized study carried out in a Birth Center located in São Paulo city to evaluate the efficacy of liquid petroleum jelly in reducing perineal laceration. The sample was composed of 38 nulliparous women per group (experimental and control). In the experimental group was used $30 \mathrm{ml}$ of the petroleum jelly in the perineal region during the expulsive period. The parturient were allowed to push spontaneously during the delivery and remained in the left side position. The frequency of perineal laceration was similar in both groups (experimental 63.2\% versus control $60.5 \%$ ). The posterior perineum region presented the highest frequency of trauma (53.2\%). Of the total cases of perineal trauma, $72.3 \%$ were first-degree lacerations. The use of liquid petroleum jelly of perineal protection does not reduce the frequency neither the degree of lacerations in childbirth.

DESCRIPTORS: birth injuries; perineum; petrolatum jelly; childbirth; randomized controlled trials

\section{USO DE VASELINA LÍQUIDA EN LA PREVENCIÓN DE LACERACION PERINEAL DURANTE EL PARTO}

La mayor parte de los nacimientos por vía vaginal están acompañados por laceraciones perineales. Este es un estudio aleatorio realizado en una maternidad de la ciudad de San Pablo para evaluar la eficacia de la vaselina líquida en la reducción de laceraciones perineales. La muestra fue compuesta por 38 mujeres nulíparas organizadas en un grupo experimental y otro de control. En el grupo experimental fue aplicado $30 \mathrm{ml}$ de vaselina en la región perineal durante el periodo expulsivo. Todas las parturientas realizaron "pujos" espontáneos y se mantuvieron en la posición lateral izquierda. La frecuencia de laceración perineal fue semejante en ambos grupos (experimental 63,2\% y grupo control 60.5\%). La región posterior del perineo presentó una alta frecuencia de trauma (53.2\%). De los casos totales de trauma perineal, 72,3\% fueron de laceración de primer grado. Se verificó que el uso de la vaselina en la región perineal no reduce la frecuencia o grado de las laceraciones durante el parto.

DESCRIPTORES: traumatismos del nacimiento; perineo; vaselina; parto; ensayo clínico

\section{USO DE VASELINA LÍQUIDA NA PREVENÇÃO DE LACERAÇÃO PERINEAL DURANTE O PARTO}

A maioria dos partos vaginais é acompanhada por lacerações do trato genital. Este estudo randomizado foi realizado em um centro de parto normal localizado na cidade de São Paulo, para avaliar a eficácia da vaselina líquida em reduzir o trauma perineal. A amostra foi composta de 38 nulíparas por grupo (experimental e controle). No grupo experimental utilizaram-se $30 \mathrm{ml}$ de vaselina líquida na região perineal durante o período expulsivo. Todas as parturientes realizaram "puxos" espontâneos e permaneceram em posição lateral esquerda. A freqüência de laceração perineal foi semelhante em ambos os grupos (experimental 63,2\% versus controle 60,5\%). A região posterior do períneo apresentou maior freqüência de trauma (53,2\%). Do total de casos de traumatismo perineal, 72,3\% foi de laceração de primeiro-grau.

DESCRITORES: traumatismos do nascimento; períneo; vaselina; parto; ensaio clínico

${ }^{1}$ Study extracted from the Master's Thesis; ${ }^{2}$ Nurse-Midwife, Laboratory Specialist, University of São Paulo at School of Arts, Sciences and Humanities, Brazil, e-mail: natalucia@usp.br; ${ }^{3}$ Nurse-Midwife, PhD, Faculty, University of São Paulo at School of Nursing, Brazil, e-mail: soniaju@usp.br 


\section{INTRODUCTION}

Most vaginal births are accompanied by lacerations in the genital tract, episiotomy, or both, particularly in women giving birth for the first time. First-degree lacerations often do not require suturing, and second degree lacerations can be easily sutured using local infiltration of perineum and in general heal without complications. However, third degree lacerations can have more serious consequences. These tears must be sutured by a professional to prevent problems like fistula or fecal incontinence ${ }^{(1)}$.

Despite of the decrease in the frequency of episiotomy in recent years, overall rates of perineal trauma remain high ${ }^{(2)}$. Study ${ }^{(3)}$ about episiotomy rates around the world revealed that the use of this surgery ranged from 9.7\% (Northern Europe - Sweden) to $96.2 \%$ (South America - Ecuador), with the episiotomy rates tend to be lowest in English-speaking countries (North America - Canada: $23.8 \%$ and United States: $32.7 \%$ ) and in many countries (Central and South America - Brazil: 94.2\%, South Africa - 63.3\% and Asia - China: $82 \%$ ) remain very high. Clinical trials indicate that over half of the women without episiotomy have lacerations that require suturing ${ }^{(2)}$. It is known that perineal non-sphincter injuries in connection with episiotomy sometimes cause postpartum perineal pain and incontinence ${ }^{(4)}$. Furthermore, studies have documented that episiotomy causes more pain, sexual dysfunction, and infection than perineal tearing, which has as negative impact on the women's health in postpartum period ${ }^{(5)}$. Moreover, there is no agreement about which risk factors increase or decrease perineal trauma ${ }^{(5-8)}$

In view of the magnitude of perineal morbidity, interventions which aid in the reduction of perineal trauma are desirable. Among the practices employed to protect the perineum are perineal massage, spontaneous push, vertical and lateral birth positions, the perineal protection technique for cephalic delivery and use of warm compresses and lubricants in the perineum during the expulsive period ${ }^{(6,9-10)}$. A systematic review of techniques used to prevent perineal trauma during childbirth did not show an optimal maneuver for perineal laceration ${ }^{(8)}$.

Frequently, petroleum jelly is used in the perineum during the expulsive period in the normal birth to prevent the lacerations and facilitate the delivery. However, there are no clinical studies that indicate this benefit. With the aim of reducing interventions and the medicalization of birth, it is important to evaluate ways of reducing spontaneous lacerations of the pelvic floor to reduce morbidity during labor. The authors decided to carry out a randomized controlled trial (RCT) given the lack of evidences of effectiveness of the petroleum jelly for reducing perineal trauma.

The aim of this study was to evaluate the efficacy of liquid petroleum jelly in reducing perineal laceration.

\section{METHODS}

This is a randomized study about the use of liquid petroleum jelly on the perineum during the expulsive period of labor in women who had not had previous vaginal birth. It was carried out in the Amparo Maternal, a philanthropic hospital, located in the southern region of São Paulo city, Brazil. In this center women from all parts of the city are supported and there are approximately 900 births per month. During two months (August and September 2001) occurred 1.458 (79\%) normal births, 379 (20.5\%) Caesareansection and $9(0.5 \%)$ forceps, approximately $45 \%$ of the birthing women were nulliparous and almost onequarter of women were 19 years old or less (Amparo Maternal clinical data service).

In this service, a team of obstetricians is responsible for admitting women in labor and the nurse-midwife attends these women during the labor and normal birth. The used the liquid petroleum jelly in the perineal region during the expulsive period is a usual practice among nurse-midwives of this maternity.

Participants and sample

Participants were included in the study if they met the following criteria: no previous vaginal births; age equal to or greater than 15 years (on this service, there is an elevated number of teenagers); gestational age between 37 and 41 6/7 weeks; live single cephalic fetus with no abnormality detected; uterine height no more than $36 \mathrm{~cm}$; cervical dilatation of $5 \mathrm{~cm}$ or less; no perineal preparation during pregnancy (data given by the birthing woman); no infection procession in the perineal region; to agree to use the lateral left size position during delivery (this position is more comfortable and may increase the woman's sense of control and can decrease the episiotomies rates $\mathrm{RR}=0.84 ; 95 \%$ CI 0.79 to 0.91$)^{(11)}$. 
The exclusion criteria were: use of oxytocin infusion or other drugs which could interfere in labor; obstetrical conditions during labor and delivery which required intervention as episiotomy, forceps and cesarean. Women were also excluded if they chose to deliver in the lithotomic position.

The eligibility criteria were followed by 106 women, one did not consent and 29 were excluded of the study - 27 for episiotomy and 2 for Caesariansection (Figure 1). The final sample consisted of 76 women, who were distributed 38 in the experimental group (liquid petroleum jelly in the perineal region) and 38 in the control group (routine care) during the expulsive period. The randomization was computer-generated random numbers and applied in the moment of delivery to women who followed including criteria.

A previous study ${ }^{(12)}$ at the same maternity service reported that perineal lacerations occurred in $50 \%$ of nulliparous women without episiotomy, $37 \%$ of these women had first-degree lacerations and $13 \%$ had second-degree lacerations. The sample size was calculated using the formula proposed by Lwanga; Lemeshow ${ }^{*}$, which is used to compare finite population proportions. The number of participants considered necessary were 76 ( $n=38$ per group). A power analysis indicated that a sample size of 38 women per group would give $80 \%$ power to detect the difference of $30 \%$ perineal lacerations between groups, with an $\alpha=.05$.

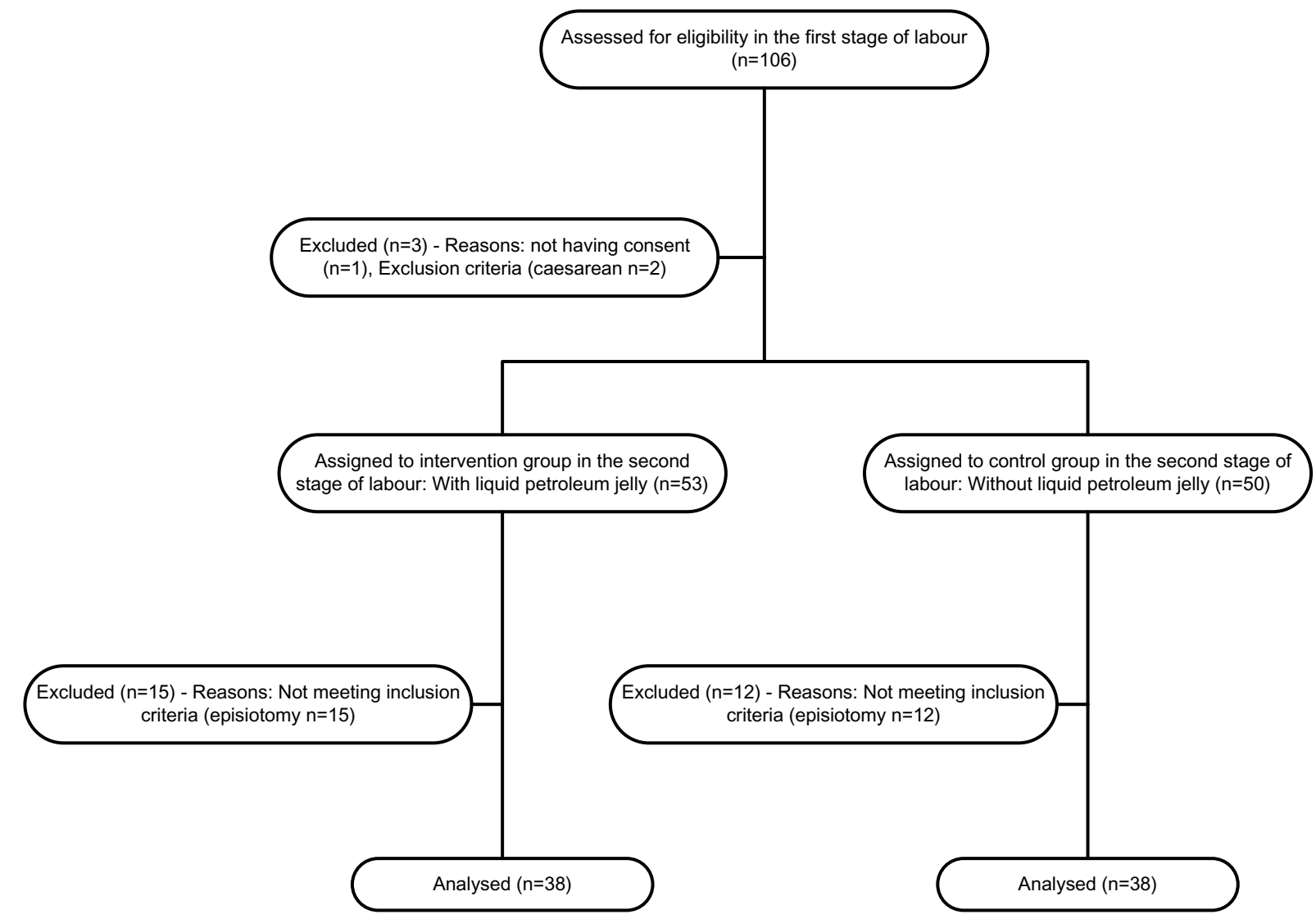

Figure 1 - Flow diagram of trial participants: initial and final inclusion

Data collection

Data were collected from February through June 2003 by the researcher, nurse-midwife, who attended $74(97.4 \%)$ childbirths of this study, and by two nurse-midwives of the staff. The nurse-midwives were informed about which group (control or experimental) the woman was allocated by the researcher when the woman was in the expulsive period. In the expulsive period, the woman was transferred to the labor delivery room where she remained in the left side position. During delivery the right foot was supported from above and the head was slightly elevated with a pillow.

The perineum skin antisepsis is made by using liquid soap and following skin preparation, as much

* Lwanga SK, Lemeshow S. Sample size determination in health studies: a practical manual. Geneva, World Health Organization, 1991. 
of the prepared area as possible is covered with sterile drapes, for both groups. In the experimental group, the petroleum jelly was applied to the entire area of the perineum with two fingers, using a sweeping motion. The clitoris, labia majora, labia minora, vestibule, fourchet and perineal body were covered with $30 \mathrm{ml}$ of this lubricant without any stretching or massage of the perineum. It was done time after time, from the complete cervical dilation until the beginning of the cephalic delivery. All birthing women were allowed to push spontaneously during the delivery, without being directed in bearing down efforts.

For both groups, the women received the routine care from the Normal Birth Center. The control group only did not receive the petroleum jelly application.

\section{Study variables}

The use of liquid petroleum jelly and routine care in the perineal region during delivery was the independent variable. The dependent variables were (perineal conditions - frequency, degree, and location of perineal laceration - and newborn outcomes evaluated by the Apgar score). For this study, the expulsive period length is defined as the time (minutes) between the full cervical dilatation diagnosis and the fetal delivery ${ }^{(13)}$. The expulsive efforts and uterine contractions were used as an indicative to perform the vaginal examinations and verify the cervical dilation.

Ethical considerations

This study was approved by Research and Ethic Committee of The School of Nursing, University of São Paulo and data collection was authorized by Clinical Head of the maternity were the research took place. The women were invited to participate after her admission in the Birth Center. Before inclusion of the women in the study, the purpose and the methods of this study were explained to every one woman. A signed consent was obtained from all voluntary participants, who were assured the right to withdraw from the study at any moment.

Data analysis

The characteristics of the women have been described using means for quantitative variables and proportions for qualitative variables. The statistical analysis was processed using the "SPSS for Windows" program, version 10.0. All tests (Chi-square, Student $t$, Pearson and Fisher exact) performed were twotailed, and $p$-values of $<0.05$ were considered significant.

\section{RESULTS}

The final sample was 76 nulliparous distributed in two groups (38 experimental and 38 control). The groups were homogenous with regard to height (160.0 $\pm 0.1 \mathrm{~cm}$ ), age (experimental $21.6 \pm 3.8 \mathrm{yr}$ and control $20.5 \pm 3.9), 32(42.1 \%)$ participants were Caucasian and $50(65.8 \%)$ women were unemployed. Fetal presentation was occipitopubic in $97.4 \%$ (74) of the births. The neonatal outcomes were good in both groups, with median Apgar scores of 9 and 10 at 1 and 5 minutes, respectively, in two groups.

The length of stay of the petroleum jelly on the perineal region until the beginning of the cephalic delivery was from 3 to 40 minutes, with a mean of $16.4 \pm 9.9$ minutes.

Table 1 - Perineal condition after birth, according to group. Amparo Maternal, 2003

\begin{tabular}{|c|c|c|c|c|c|c|c|}
\hline \multirow{4}{*}{ Perineal outcome } & \multicolumn{4}{|c|}{ Group } & \multirow{2}{*}{\multicolumn{2}{|c|}{ Total }} & \multirow{4}{*}{ p } \\
\hline & & & & & & & \\
\hline & \multicolumn{2}{|c|}{ Experimental } & \multicolumn{2}{|c|}{ Control } & \multirow[b]{2}{*}{$\mathbf{N}$} & \multirow[b]{2}{*}{$\%$} & \\
\hline & $\mathbf{N}$ & $\%$ & $\mathbf{N}$ & $\%$ & & & \\
\hline Intact $(n=29)$ & 14 & 36.8 & & 39.5 & 29 & 38.2 & \\
\hline Trauma $(n=47)$ & 24 & 63.2 & 23 & 60.5 & 47 & 61.8 & $0.813^{a}$ \\
\hline \multicolumn{8}{|l|}{ Degree of tear } \\
\hline $1^{\text {st }}$-degree tear $(n=34)$ & 16 & 66.7 & 17 & 78.3 & 34 & 72.3 & \\
\hline $2^{\text {nd }}$-degree tear $(n=13)$ & 08 & 33.3 & 05 & 21.7 & 13 & 27.7 & $0.347^{\mathrm{a}}$ \\
\hline \multicolumn{8}{|l|}{ Region of tear } \\
\hline Posterior $(n=25)$ & 13 & 54.2 & 12 & 52.2 & 25 & 53.2 & \\
\hline Anterior $(n=14)$ & 07 & 29.2 & 07 & 30.4 & 14 & 29.8 & \\
\hline Anterior and posterior $(n=8)$ & 04 & 16.6 & 04 & 17.4 & 08 & 17.0 & $>0.999^{\circ}$ \\
\hline
\end{tabular}

a Chi-square ${ }^{b}$ Fisher

In terms of overall perineal outcomes, $38.2 \%$ had an intact perineum and $61.8 \%$ had perineal laceration. The proportion of birthing women who presented laceration was similar in both groups (experimental $63.2 \%$ vs. control $60.5 \%$ ), without statistical difference $(p=0.813)$.

Of the total cases of perineal trauma $(n=47)$, $72.3 \% \quad(n=34)$ were first-degree lacerations (experimental $66.7 \%$ vs. control $78.3 \%$ ). The seconddegree laceration had a higher frequency in the 
experimental group $(n=8 ; 33.3 \%)$, without statistical difference $(p=0.347)$. The posterior perineum region presented the highest frequency of trauma $(n=25$; $53.2 \%)$.

Table 2 - Comparison of the means of the weights (newborn, mother), duration of $2^{\text {nd }}$ stage and perineal outcome. Amparo Maternal, 2003

\begin{tabular}{|c|c|c|c|c|c|c|}
\hline \multirow[b]{2}{*}{ Mean } & \multicolumn{3}{|c|}{ Experimental group } & \multicolumn{3}{|c|}{ Control group } \\
\hline & $\begin{array}{l}\text { Intact } \\
(n=14)\end{array}$ & $\begin{array}{c}\text { Tear } \\
(n=24)\end{array}$ & p & $\begin{array}{l}\text { Intact } \\
(n=15)\end{array}$ & $\begin{array}{c}\text { Tear } \\
(n=23)\end{array}$ & $\mathbf{p}$ \\
\hline $\begin{array}{l}\text { Mean length } 2^{\text {nd }} \\
\text { stage (min) }\end{array}$ & $33.0 \pm 16.2$ & $37.6 \pm 19.3$ & 0.445 & $38.7 \pm 20.2$ & $31.5 \pm 16.6$ & 0.238 \\
\hline $\begin{array}{l}\text { Mean weight of } \\
\text { mother }(\mathrm{Kg})\end{array}$ & $68.7 \pm 7.6$ & $73.7 \pm 9.1$ & 0.094 & $64.8 \pm 5.9$ & $64.6 \pm 10.5$ & 0.952 \\
\hline $\begin{array}{l}\text { Mean newborn } \\
\text { weight }(\mathrm{g})\end{array}$ & $3,230 \pm 260$ & $3,240 \pm 440$ & 0.878 & $3,020 \pm 340$ & $3,130 \pm 310$ & 0.309 \\
\hline
\end{tabular}

The newborn weight mean in the experimental group $(3,240 \mathrm{~g})$ was higher than in the control group $(3,090 \mathrm{~g})$. The data show that there was no relation between the degree of perineal laceration and the newborn weight, the maternal weight and expulsive period length.

A large variation in length in the second stage of labor was observed (range $8 \% 115$ minutes). The mean was perineal intact (33.0 minutes) vs. tear (37.7 minutes) in the experimental group; and was perineal intact (38.7 minutes) vs. tear (31.5 minutes) in the control group.

\section{DISCUSSION}

Initially, will be considerations about the limitations of the study. The lack of blinding may have affected the assessment of perineal outcomes. However, there was no possibility that the researcher did not have identified a tear that requiring suture. In this case, the bias introduced by researcher would be minimizing the perineal trauma in the experimental group. In fact, the gold standard design for assessing the intervention is held to be the double blind randomized trial. However, in general blinding is impossible when the intervention is a highly visible component of care.

This study is the first randomized trial which evaluates the use of petroleum jelly in the perineum during childbirth. The results showed that petroleum jelly use did not prevent perineal trauma, since the laceration rates were similar in both groups $(63.2 \%$ experimental versus $60.5 \%$ control). Among the 76 women who took part in the study, $38.2 \%$ presented intact perineum, showing that lacerations are very frequent in the spontaneous vaginal births (Table 1). Similar rates of trauma were found in a vaginal birth study ${ }^{(4)}$, with $73.3 \%$ of primiparous and most women delivering in the lateral, semi-recumbent or kneeling positions. Another study ${ }^{(10)}$ which evaluated the perineal massage effect with water-soluble lubricant during the expulsive period, also showed similar rates of spontaneous laceration (60.9\% massage group versus $63.6 \%$ control), without statistical difference.

In contrast, a prospective non-randomized study $^{(6)}$ which evaluated 1,211 spontaneous vaginal births attended by nurse midwives, concluded that the warm compresses and perineal lubrification during the expulsive period were associated with an increase in perineal laceration. The laceration proportion was statistically higher in women who used water-based lubricant (50\% vs. $26 \% \mathrm{p}<0.001)$.

A study ${ }^{(2)}$ carried out with 3,049 births assisted by nurse midwives and students evaluated the factors related to perineal trauma on birth. The lateral delivery position and warm packet compress use were associated with a reduction in trauma, due to the increase in supply blood, which makes it easier for the tissues to relax. In the logistic regression model, the use of lubricant or oil during the expulsive period increased the laceration risk in the group of multiparous women $(\mathrm{OR}=1.7)$.

In a recent randomized study ${ }^{(14)}$ of 1,211 births in midwifery care, a higher level of genital tract trauma occurred in mothers offered one of the three intervention (warm compresses, massage with watersoluble lubricant, or hands off) were used late in the second stage of labor. The frequency distribution of obstetric laceration was equal with three interventions with $77 \%$, and $40 \%$ of all study participants were nulliparous and approximately $80 \%$ of women were sitting upright when giving birth.

Multiple regression analysis revealed a statistically significant association between birth position and perineal outcome. Overall, the lateral position was associated with the highest rate of intact perineum $(66.6 \%)^{(15)}$.

More recently, of the 19 trials included in a Cochrane review on woman's position during the second stage of labour, the use of any upright or lateral position when compared with supine or lithotomy positions, was associated with: reduced duration of 
second stage of labour; a reduction in episiotomies; an increase in second degree perineal tears ${ }^{(11)}$.

In the present study, among the perineal trauma $72.3 \%$ were first-degree lacerations considering the women who needed perineal repair and $27.7 \%$ were second-degree lacerations. The firstdegree laceration was the most frequent in the control group, with $78.3 \%$ vs $66.7 \%$ for the experimental group, without any statistical difference (Table 1 ). Third and fourth degree lacerations were not observed. These types present higher morbity, and include anal incontinence, post partum pain, infection and sexual dysfunction.

Similar data were found in a study ${ }^{(10)}$ with massage in the second stage of labor, with $35.7 \%$ presenting second-degree lacerations in the massage group and $35.5 \%$ in the control group. The authors concluded that perineal massage use in labor does not increase the occurrence of intact perineum.

A prospective observational study ${ }^{(4)}$ found in nulliparous, assisted by midwives, the lower frequency of first-degree laceration (34.8\%) and more elevated second-degree lacerations (38.5\%), compared to the present study.

Another prospective study ${ }^{(16)}$ that included 1,068 births attended by nurse midwives observed that first-degree lacerations occurred in $22.2 \%$ of the nulliparous and $11.7 \%$ of the multiparous women. The second-degree lacerations occurred in $31.5 \%$ of the nulliparous and $10.5 \%$ of the multiparous. The authors concluded that in nulliparous the factor associated to the perineal trauma was massage during labor.

Regarding to the laceration location, the results showed no difference between the groups; however, the posterior region of the perineum presented higher trauma frequency in both groups; $54.2 \%$ in the experimental and $52.2 \%$ in the control, with a higher frequency in the median region (Table 1). A possible explanation for the higher occurrence of trauma to the posterior region could be the pressure of one of the hands above the fetal head, which prevents extension movement, forcing it away from the pubic arch and toward the posterior region of the perineum, making it easier for laceration to occur ${ }^{(1)}$.

Study ${ }^{(4)}$ evaluated genital tract trauma during labor in 1,296 nulliparous with and without episiotomy. It was observed that first-degree tear in the no episiotomy group $38.9 \%$ in the anterior region of the perineum, which agrees with the present data (30.3\%). We also can highlight that the $66.1 \%$ of the lacerations (I and II degree) occurred in the posterior region of the perineum, which is in accordance with the present data $(60.6 \%)$.

In our study no relation between perineal condition and expulsive period length was found. Different results were observed in study ${ }^{(17)}$ which found higher rates of intact perineum in the women who had longer expulsive periods (83.5 vs 39.8 minutes) $(p=0.001)$. Another study ${ }^{(4)}$ demonstred that stepwise logistic regression analysis revealed that duration of second stage of labor $>60 \mathrm{~min}(\mathrm{OR}=1.307$ $95 \%$ CI 1.027 to 1.663 ) remained independently associated with second-degree tear.

A study ${ }^{(7)}$ of the risk factors related to third degree laceration during birth found a significant increase $(O R=1.12)$ when the expulsive period was longer than 15 minutes. The authors concluded that the stretching of perineal muscles for an extended period of time can lead to local ischemia, which can increase perineal ruptures.

Data indicate that the groups were homogeneous regarding newborn weight. However, higher mean values occurred in the experimental group (Table 2). The newborn weight was not associated with perineal trauma when the data were adjusted for parity and other related variables in study ${ }^{(2)}$. In the other study ${ }^{(4)}$ a logistic regression analysis revealed that higher infant weight remained independently associated with second-degree tear (OR=1.801 95\% CI 1.529 to 2.123).

\section{CONCLUSIONS}

Perineal trauma is a common occurrence during vaginal delivery, with no relation to the parity. Pain is a frequent complaint from post-partum women and it interferes in their daily activities as well as in their interaction with the newborn and family. Our study has focused on the efficacy of petroleum jelly in perineum protection during delivery. The results show that the use of liquid petroleum jelly in the perineum during the expulsive period does not reduce the occurrence and the degree of perineal laceration. It is very important to reduce the morbidity related to the perineal trauma after birth. Maintaining the integrity of the perineal region is a serious challenge for caregivers. 


\section{REFERENCES}

1. Organização Mundial da Saúde-OMS. 1996. Assistência ao parto normal: um guia prático. Brasília (DF): OPAS/USAID. [OMS/SRF/MSM/96.24].

2. Albers LL, Anderson D, Cragin L, Daniels SM, Hunter C, Sedler KD et al. Factors related to trauma in childbirth. J Nurse Midwifery 1996; 41(4):269-76.

3. Graham ID, Carroli G, Davies C, Medves JM. Episiotomy rates around the world: an update. Birth 2005; 32(3):21923.

4. Samuelsson E, Ladfors L, Lindblom BG, Hagberg H. A prospective observational study on tears during vaginal delivery: occurrences and risk factors. Acta Obstet Gynecol Scand 2002; 81(1):44-9.

5. Larsson PG, Platz-Christensen JJ, Bergman B, Wallsterson G. Advantage or disadvantage of episiotomy compared with spontaneous perineal laceration. Gynecol Obstet Invest 1991; 31(4):213-6.

6. Lydon-Rochelle MT, Albers L, Teaf D. Perineal outcomes and nurse-midwifery management. J Nurse Midwifery 1995; 40(1):13-8.

7. Leeuw JW, Struijk PC, Vierhout ME, Wallenburg HCS. Risk factors for third degree perineal ruptures during delivery. BJOG $2001 ; 108(4): 383-7$

8. Eason E, Labrecque M, Wells G, Feldman P. Preventing perineal trauma during childbirth: a systematic review. Obstet Gynecol 2000; 95(3):464-71.

9. Sampselle CM, Hines S. Spontaneous pushing during birth relationship to perineal outcomes. J Nurse Midwifery 1999; 44(1):36-9.

10. Stamp G, Kruzins G, Crowther C. Perineal massage in labour and prevention of perineal trauma: randomised controlled trial. BMJ 2001; 322(26):1277-80.

11. Gupta JR, Hofmeyr GJ. Position in the second stage of labour for women without epidural anaesthesia (Cochrane Review). In: The Cochrane Library, Issue 1, 2006. Oxford: Update Software.

12. Silva FMB, Oliveira SMJV, Koiffman MD, Osava RH. Caracterização de parturientes atendidas em um centro de parto normal. In: Anais do $2^{0}$ Encontro Internacional de Pesquisa em Enfermagem: Trajetória Espaço-Temporal da Pesquisa; 2002 out. 28-31; Águas de Lindóia. [CD-ROM] São Paulo: EEUSP; 2002.

13. Rezende J. Obstetrícia. $10^{\mathrm{a}}$ ed. In: O parto. Estudo clínico e assistência. Rio de Janeiro: Guanabara Koogan: 2005. p.338-62.

14. Albers LL, Sedler KD, Bedrick EJ, Teaf D, Peralta P. Midwifery care measures in the second stage of labor and reduction of genital tract trauma at birth: A randomized trial. J Midwifery Women's Health 2005; 50(5):365-72.
15. Shorten A, Donsante J, Shorten B. Birth position, accoucheur, and perineal outcomes: informing women about choices for vaginal birth. Birth 2002; 29(1):18-27.

16. Murphy PA, Feinland JB. Perineal outcomes in a home birth setting. Birth 1998; 25(4): 226-34.

17. Klein MC, Janssen PA, MacWilliam L, Kaczorowski J, Johnson B. Determinants of vaginal-perineal integrity and pelvic floor functioning in childbirth. Am J Obstet Gynecol 1997; 176(2):403-10. 